\title{
LEXICAL AND GRAMMATICAL MEANS OF EXPRESSING THE IMPERATIVE NATURE OF A LEGAL DOCUMENT IN UKRAINIAN AND ENGLISH
}

\section{Savchuk H. V.}

\section{INTRODUCTION}

In jurisprudence language acts as a multidimensional phenomenon are an object of legal regulation, a means of legislative and law enforcement.

The language of legal documents is a specific one with clarity, conciseness and determinacy, an imperative nature of presentation, special terminology that expresses the accuracy of the thoughts of the legislator.

The word plays a key role in any version of the presentation of thought, including the regulatory text. A word is both a concept and a term with respect to which there exist certain requirements. As a rule, the required clarity, ambiguity, self-explicability and conciseness of the dictionary of a legal document are talked about.

The imperative, included in the rule of law, expresses the attitude defined by the legislator, and the logical basis of the imperative is both a regulation and prescriptive statement. Such interrelation means that will expresses its due and is subject to execution. If particular situations are not desired by the legislator, then the legal norms are formulated in such a way that certain forms of human behavior contributing to happening of such situations receive an appropriate assessment, i.e., illegitimate. Legal imperatives, therefore, have illocutionary forces of motivation and caution, however are not limited to them, since any command is caused by a possibility of its performance (a condition of success of directive illocutionary acts). Thus, the semantics of the imperative, therefore, includes not only the command of the legislator, but also that which can be imputed to the duty and obligation of the legal entity by this command. From this perspective, the commands are also caused by the legal possibility of carrying out the actions desirable to the legislator, i.e., the availability of appropriate conditions, guarantees, legal and relevant regulatory procedures by which the requirement is fulfilled and acquires the characteristic of due. From a linguistic and cultural point of view, legal systems are not just an autonomous, closed world of norms, but, above all, 
an expression of the value components of national culture (certain ideas about law, justice, the concept of a legal entity, judicial practice, etc.). In this regard, the purpose of legal imperatives consists not only in the application of logic at law-making and law-enforcement activity, but also in the implementation of cultural values. From this standpoint, law acts as a symbolic space of unity of speech forms and meanings of culture, behind which there are legally significant action, events, relations, interests and the long history of law and culture in general.

The values of culture expressed in legal imperatives (law, freedom, legitimate interest, honour, dignity, reputation, private life, the public good, harm, etc.) are used in various discourse forms, i.e., speech acts, genres and scenarios of legal discourse. The legal version of social reality, its semantic organization, is provided, exists and changes through the socially important action of legal entities, by means of legal imperatives.

Therefore, the legal imperative must be adequate to the social interests, meanings and values of culture, acting as a criterion for its legitimation. It should be noted that various speech acts through which strong-willed decisions of the participants about the desired or not desired action are communicated, receive their legal significance due to the fact that they are the implementation and application of legal imperatives included in the rule of law, i.e., result from the obligation of interrelated regulatory orders. Otherwise, if someone orders, demands, requests, offers, decide something, and then it does not mean that other participants of the legal discourse should behave in accordance with this will.

In this regard, the ability to act in legal discourse can be referred to the performative characteristics of imperative speech acts of the legislator, operating as a constitutive basis for a variety of communicative action, including requirements aimed at the implementation and restoration of rights.

Thus, in the structure of legal imperatives, the speaker's attitude to the possible reaction of the addressee is already implied. The illocutionary force of the imperative is determined by the regulatory context and is related to the social significance of the requirement expressed by it.

So, the most significant legal imperatives expressing the key value meanings of culture are included, first of all, in constitutional norms, exhibiting the highest legal force and, accordingly, the highest degree of urgency. Consequently, the legal force of the imperative, included in the rule of law, is directly related to its illocutionary force. The illocutionary goal of legal imperatives is to make what is due to be a reality. In itself, a 
requirement does not make sense in legal discourse if it is not prescribed to obey it, resulting from the normative context.

\section{Imperative nature as a primary style feature of a legal document}

For linguistic studies of the past few decades, it is characteristic that imperative and categories of inducement are studied in compliance with the theory of speech acts. These are works by John Searle, M.M. Bakhtin, N.D. Arutyunova, N.O. Bezmenova.

While performing the speech act, the speaker affects the hearer in terms of changing his thoughts, mental state, prompts him to act, etc. The speech act being an intermediary between the sender of the message and his goal is divided into three constituents: an act of pronouncing (locution); an act of predicting (suggestion); an act of giving a communicative (illocutionary) power to an expression: an order, a promise, a statement, a request, etc., then perlocution is singled out: an act of speaking or writing which has an action as its aim but which in itself does not affect or constitute the action, for example persuading or convincing.

Generally, illocutionary acts make up the bulk of the language, not just specific ones. In accordance with illocutionary power, purpose, and function, speech acts are divided into the following classes: representatives; directives; commissives; expressives conveying emotional states; etiquette, courtesy formulas; declarations etc. Large speech acts are usually mixed; to put it more precisely, they can be distinguished by different classes and types of elements.

In studies of the speech act, an important place belongs to the personal positions of the participants of the act, their attitude to the truth of the spoken. Compliance with the speech, expressing the intentions of the speaker, i.e., his sincerity is recognized as compulsory (public opinion).

John Searle identified five classes of speech acts: representatives informing the hearer about the state of affairs in reality; directives that represent the attempt of the speaker to get the hearer to do something; commissives by which the speaker has an obligation to perform a certain action; expressives conveying the psychological state of the speaker; declarations making changes to the status of the objects mentioned by the very fact of pronunciation ${ }^{1}$

L. A. Biryulin and V. S. Khrakovsky draw, in turn, on the three-level representation of utterances adopted in the theory of speech acts as a model of the structure of the content of the inducing utterance, which includes: 1)

\footnotetext{
${ }^{1}$ Novoye v zarubezhnoy lingvistike [New in foreign linguistics] (1996). Moscow: Progress. (in Russian)
} 
a plan of binding over order (illocutionary act), having the Prescriptor, the Recipient of an order, and Doer of an order; 2) a plan of communication (locutionary act), including the Speaker, hearer/hearers (Recipient/ Recipients) and the Person/ Persons not participating in the communicative act; 3) a plan for a causable state of things (propositional act) ${ }^{2}$.

Within the scope of inducing utterances, specific subtypes of (“order”, "request”, "proposal”, etc.) are traditionally distinguished, which differ in a number of parameters, such as the degree of urgency of the , subordination of participants in the act of communication, and inactivity (for the benefit of the speaker, the addressee or someone else is supposed to carry out a causable action), provoked / unprovoked act of the definiteness / indefiniteness of the reference, etc. Expressing the imperative structure, all of these subtypes of motivation can be marked by the intonation, lexical meaning of the imperative form, as well as the context and situation of utterance, etc ${ }^{3}$.

A.N. Baranov considers 4 types of (order, request, advice, and offer). The above-mentioned semantic interpretations of represent abstractions that can fall into a number of more specific subtypes of or single out a subtype of marked by some specific characteristic.

For example, L. A. Sergiyevska considers the main types of commands and their connotations: order (connotations are an order, requirement, prohibition, command), appeal (connotation is a slogan), suggestion (connotations are an invitation, order, wish), request (connotations are a prayer, comfort, statement), advice (connotations are an instruction, cautionary advice, warning, and clarification) ${ }^{4}$.

Very often we are dealing with a kind of transitional case where the may be perceived ambiguously. Often such ambiguity, when an order is conveyed through the request and a warning is expressed through the advice, is initially conceived by the speaker. It should be remembered that the above-mentioned subtypes of are not discrete objects, but also a kind of micro-field with a core (when this subtype of is unambiguously and consistently expressed by a certain structure conventionalized in the language for this subtype) and more or less blurred periphery (when it comes to all kinds of transpositional processes and when the correct

\footnotetext{
${ }^{2}$ Biryulin L. A., Khrakovskiy V. S. (1992) Povelitel’noye predlozheniye. Tipologiya imperativnykh konstruktsiy [An imperative sentence. Typology of imperative constructions]. Moscow: Nauka. (in Russian)

${ }^{3}$ Vezhbitskaya A. (1985) Rechevyye akty. Novoye v zarubezhnoy lingvistike [Speech acts]. Moscow: Progress. (in Russian)

${ }^{4}$ Sergiyevskaya L. A. (1995) Slozhnoye predlozheniye s imperativnoy semantikoy v sovremennom russkom yazyke [A complex sentence with imperative semantics in modern Russian] (Doctorate thesis), Moscow: Moscow Pedagogical University.
} 
interpretation of involves taking into account both actual linguistic and other factors).

Recently, in many modern scientific studies, the meanings of inducement are included in the linguistic category of modality, forming in it its subsystem the (directive) modality. In this perspective, the directive modality combines means of different levels whose semantic function is to induce the hearer or another person to perform an action or change the state of affairs.

The notion of the structure of a speech act helps in the study of the mechanisms of speech, understanding of the complex processes of preparation, actualization of utterances, their perception and understanding, as well as results and consequences.

Subsequently, some researchers have observed that different speech acts do not exist on their own, but are combined in neighboring utterances in the text. For example, the text of courtroom public speech (its verbal and non-verbal components) can perform various functions, combining assertives (information about the details of the murder and the motive for the crime), expressives (conveying the psychological state of the forensic orator by showing sympathy to the victim's relatives) and other speech acts. At the same time, the pragmatic focus of courtroom public speech is always a directive that encourages the guilty of crime to commit a certain action that is advantageous to the forensic orator ${ }^{5}$.

In jurisprudence, the concept of "legal document" has a clear definition. A legal document is interpreted as an external verbally-formed expression of will that secure legitimate or offending behavior and the corresponding result. A legal document is a textual medium of official legal information (norms, rights and obligations, prohibitions, etc.), and it has a number of features.

It is customary to distinguish the following characteristics of legal documents:

1) they contain information of legal significance; while the contents should correspond to the nature of the document;

2) they have official character due to the bodies or persons authorized to issue or receive these documents;

3) they have an external design, the so-called requisite elements, or information about the subject and addressee of the legal document. The abovementioned requisite elements give any legal document validity;

\footnotetext{
${ }^{5}$ Rohozha V. H. (2005) Zasoby vyrazhennia volovoi modalnosti v tekstakh kodeksiv Ukrainy [Means of expression of volitional modality in the texts of the codes of Ukraine]. Extended abstract of PhD Thesis. Kyiv: NAS of Ukraine, Institute of Ukrainian Language.
} 
4) they accompany all stages of legal regulation, i.e., legal creativity, enforcement of the right, etc.

The concept of legal document is absent in the legislation of Ukraine. The Legislation, in particular, defines the term as an official document, i.e. it is a written confirmation of the facts and events of legal significance, the emergence, change or violation of the rights and responsibilities of individuals or legal entities; an official document is a document drawn up, issued, certified by a lawful person in compliance with the norms, who is entitled by law to draw up, issue, certify certain types of documents in view of his professional or official activity, which confirms certain events, phenomena, facts, and containing the requisites and particulars provided by law.

However, the concepts of legal document and official document are not identical. The term for a legal document is broader than the last one, i.e., every official document is a legal document, but not every legal document has official characteristics.

The current legislation stipulates the requirements for the form and content of official documents, their specific types used in a particular case, the specific persons empowered to draw up and publish them. Therefore, official documents have the following characteristics: 1) clearly established procedure for drafting, certification, publication; 2) a duly drafted entity, endowed with relevant legislative acts; 3) mandatory compliance with the established structure of the requisites; 4) confirms or certifies certain events, phenomena or facts that are within the sphere of regulation of legal relations.

Unlike official documents, legal documents can be drawn up not only in the official field (which is a mandatory requirement for official documents), but also in private and personal, developed by both individuals and legal entities, can be official, and unofficial, which gives the form and content of the legal document more flexibility than official documents that require more stringent requirements ${ }^{6}$.

Therefore, a legal document is the carrier and legally relevant information to which norms of affair relate to the emergence, alteration or termination of a legal relationship, which in accordance with the rules of law serves as the basis or confirmation of the rights and obligations of the participants in these legal relationships.

6 Hyliaka O. (2014) Yurydychnyi dokument: osoblyvosti ta zakonodavche vykonannia [Legal document: specifics and legislative implementation]. Visnyk Natsionalnoi akademii pravovykh nauk Ukrainy. Pp. 165-171. 
A legal document is a purely theoretical work of scholars of different scientific disciplines such as forensic linguistics, jurisprudence, scientific discipline of documentation. Therefore, a legal document is a legally relevant information carrier, which in accordance with the rules of law serves as the basis or confirmation of the rights and obligations of the participants in these legal relationships.

Ye. O. Michurin distinguishes the following characteristics of a legal document: 1) material form (a legal document, like all other documents, created in the form of tangible media: a paper document, an electronic document, or even in the form of things); 2) informative (a document contains information in different formats that can be perceived by people; 3) legal force (such a document either engenders or confirms the legal rights and obligations of participants in certain legal relationships. This is the main functional purpose of this type of documents. In this regard, there is every reason to believe that drafting a legal document can be regarded as a legal matter that is intended to lead to certain legal consequences; 4) legal certainty of the document status (the rules of law contain instructions for the existence of legal documents, the possibility of their use in a particular situation for certain legal purposes). This feature implies that the legal consequences of the use of such documents are determined and fixed by the rules of law; 5) formality (the rules of law provide requirements for the form, content of the document and its details). Compliance with these requirements is a prerequisite for being able to use the legal document as intended. Moreover, the list of such requirements in different legal documents is different.

In official communication, not only the contents of the legal document are important, but also by whom and how it was created, as well as how it is drawn up externally. Linguistically, a legal document is a special type of text with a number of peculiar features ${ }^{7}$.

According to L.R. Duskayeva and O.V. Protopopova, the most important stylistic features of all official texts are imperative nature, accuracy, objectivity, and standardization.

Imperative nature finds its expression in the creation of a text that has a binding nature, in other words, it imposes as a duty, permits, prohibits any action or gives an option right. The imperative nature is especially evident in legislative texts, documents of legal proceedings and etc., in

\footnotetext{
${ }^{7}$ Duskayeva L. R., Protopopova O. V. (2011) Stilistika ofitsial’no-delovoy rechi [Stylistics of official speech]. Moscow: Akademiya. (in Russian)
} 
which the legal norms are stated in the form of a must-prescriptive and stating-prescriptive methods.

Imperative nature is the chief stylistic feature of the official style. The essence of the imperative in relation to legal documents is to express the requirements in the form of legal norms. Depending on the nature of the requirement, legal norms are divided into binding, empowering and prohibiting. Binding norms assign certain obligations to participants in legal relations. Here one can observe the prevailing wording with "must", "obligated". The authorizing norms allow taking certain actions and give the participants of regulated relations certain rights. The words "may", "entitled", "has the right" can often be found in the authorizing norms. The purpose of prohibitions is to establish the boundaries of undesirable, harmful and dangerous actions. Such words, e.g., as "not allowed", "shouldn't" are predominated in them. The essence of a direct ban is to convey the keyword "prohibited." Similar functions of the requirement, i.e., binding, empowering, authorizing, and prohibiting are distinguished in the English legal language.

\section{Lexical and grammatical means of expressing the imperative nature of a legal document in Ukrainian and English}

In most languages of the world, there are special lexical and grammatical means of expressing a directive modality. The study of these means is of great interest in different languages and professional spheres.

The means of expressing a directive modality were studied by A. O. Shakhmatov, V. O. Bogorodytsky, O. M. Peshkovsky and other researchers. A. O. Shakhmatov elaborated the most complete classification of the means of the 's expression and pointed to both morphological means (the imperative mood, forms of the past and present tense) and syntactic means (simple sentences, intonation, etc).

In all these works, the issue of directive modality, as well as the means of its expression, is raised incidentally, i.e., without detailed study. As for the special works devoted to the problem of the category of urgency in the legal sphere, it should be mentioned that there are very few in the linguistic literature.

While doing research into the vocabulary of Ukrainian and English legal documents we have noticed that its characteristic feature is the use of special vocabulary, official, and literary one. It can be explained by the constant interaction of general literary and legal vocabulary, the nature of 
law, the tendency to expand the sphere of legal regulation of almost all types of social relations.

Legal documents are also rich in clichés and fixed phrases. As a rule, a cliché is a turn of speech that is continuously occurred without creative comprehension. Examples of clichés can be the statements that are often used to express the imperative nature of a legal document: bring an action, perform a contract, render a decision, dismiss an appeal, and so on.

In legal texts the lexical means of expressing urgency are the words of the corresponding semantics, which convey the three basic meanings of a legal instruction: obligation, eligibility, and prohibition. The first group is represented by such words as undertaking, promise, covenant, mandatory, liable, duty, obligatory, order. The following words and expressions are often used to convey authorization meanings: be entitled, authorize, empower, etc. The third group consists mainly of verbs: preclude, criminalise, restrain, enjoin, disallow, prohibit, forbid, proscribe, ban, veto, and others.

A separate group of lexical means is formed by English performative verbs. Performative verbs denote declarations of will that the speaker cannot but express through the pronunciation or writing of phrases containing these verbs. These include verbs such as bequeath, order, pray promise, swear, agree, etc ${ }^{8}$. Performative verbs express the communicative task (purpose) of the whole text; using them it is easy to determine the type of the text and the nature of the relationship of the parties, as well as the degree of binding order. For example:

The Summit should agree on specific related sustainable development initiatives.

Учасники зустрічі на вищому рівні повинні домовитися про конкретні ініціативи, пов'язані зі стійким розвитком.

The imperative nature of the document is usually emphasized by means of special constructions that contain references to the will of the legislator, the statutes, instructions, the provisions of the article in a contract. For example:

Under the Constitution / the convention...

In accordance / conformity / compliance with Crimes Act...

According to the Protocol...

By virtue of this Contract...

Outlined in the in the Geneva Conventions...

\footnotetext{
${ }^{8}$ Rybin P. V. (ed.) (2018). Uridicheskiy perevod [Legal translation]. Moscow: Prospekt. (in Russian)
} 
... as stated / stipulated / indicated / specified / set out / claimed in the present

Treaty...

Керуючись ст. КЗпП України...

Відповідно до ст. 185 Податкового кодексу України...

Керуючись ст. 57 КЗпП Украӥни...

Пунктом 188.1 визначено.....

Частиною n'ятою ст. 8 Закону про ССВ визначено...

Згідно з діючим законодавством Украӥни...

Відповідно до постанови Міністерства освіти Украӥни.

The most powerful means of expressing the imperative nature of legal texts are modal verbs and their equivalents. Must is used to express an absolute liability, an order, or a duty caused by the presence of external circumstances in legal texts. For example:

Under the convention, countries must meet their targets primarily through national measures.

Страховики повинні також страхувати осіб без документів.

In legal documents, shall expresses a liability, an order, or a prohibition resulting from a law, an agreement, or other legal source. It should also be noted that shall can be found in conditional and temporal additional clauses, where one of the present tenses (Present Simple / Present Continuous / Present Perfect) is usually employed. For example:

The Parties shall be responsible for promoting and functioning nuclear research in the Member States.

Будь-яка особа, яка пред'явила позов про недобросовісність, зобов'язана протягом 15 днів після дати подання позову подати клопотання про посередництво.

$\boldsymbol{B} \boldsymbol{e}$ to expresses the need to take action in accordance with a prior agreement or decision. In terms of its meaning and use in official documents, it is almost similar to the modal 'shall'. For example:

Executor is to provide trucks for loading within time and amount agreed in the accepted Customer's order.

Замовник виконає завантаження/розвантаження та митні формальності в Україні протягом двох робочих днів для кожного перевезення.

Be obliged to expresses a duty or liability related to social, legal, and moral aspects in legal texts. For example:

A Tour Operator is obliged to provide information about the profile of services and quality, in accordance with the catalog. 
Виконавець бере на себе зобов'язання відикодувати фактичний збиток вантажу і навантажувального обладнання.

Be subject to is used to convey a duty or a possibility that depends on external conditions, but be due to expresses the liability resulting from agreements, arrangements, and contracts. For example:

Illegal entrants are subject to deportation.

Вся діяльність і всі дії поліиії регулюються Конституиією.

Brighton`s trial is due to begin on October 18.

Нинішній голова повинен піти у відставку в наступному місяиі.

Should is used for an instruction in relation to the present or future time, as well as for the need to perform an obligation, requirement.

From Art. 125 of the Constitution it follows that special jurisdiction courts should be established in Ukraine.

Кредити є недешевими, а тому їх слід використовувати лише у крайньому разі.

Undertake is legally employed to oblige to do an act claimed by the contracting party in writing. For example:

Under the delivery contract, the seller (supplier), who is an entrepreneur, undertakes to transfer in the stipulated period (term) the goods to the buyer.

За договором поставки продавець (постачальник), щзо $\epsilon$ підприємцем, зобов'язується передати в обумовлені строки (строк), товари у власність покупия.

In legal texts may expresses a possibility of performing or not performing any act, which is mostly circumstancial, but may not refers to a prohibition.

For example:

According to the Chamber's rules of procedure, every deputy may submit questions to the Government.

The court may not add other requirements, and especially may not impose conditions not in compliance with the fundamental human rights guaranteed by the Constitution and article 181 of the Labour Code ${ }^{9}$.

3 матеріалів справи можна робити витяги та знімати копії.

Особи, присутні на судовому розгляді, не можуть мати при собi зброю або небезпечні інструменти.

In Ukrainian and English legal documents be entitled to do something expresses an official opportunity or right to do any act,

\footnotetext{
${ }^{9}$ Belyaeva E.I. (1992) Grammatika i pragmatica pobuzhdeniya: angliyskiy yazyk [Grammar and pragmatics of inducement: English]. Voronezh: IVGU. (in Russian)
} 
whereas can refers to the ability to perform an act due to external circumstances. For example:

All protected persons who desire to leave the areas concerned, including foreign nationals, shall be entitled to do so in accordance with international law.

Захисник має право проводити будь-які дії, на які має право обвинувачений, в інтересах свого клієнта.

Only the assault offences can be extracted.

Вона заявила, щуо твердження про те, щуо права людини можуть порушуватися лише державами, не відповідає положенням статті 30 Деклараиії; терористи теж можуть порушувати права людини.

In affirmative sentences will is generally used for the expression of the fact of intending, perseverance, consent, or to state the intentions of the parties stipulated by the agreement. For example:

The applicant will cover the expenses related to delivering legal services.

Колишні члени компанії не будуть виконувати покладені на них функиії протягом трьох років починаючи з 1 січня 2020 року.

The strategy will include both mitigation and adaptation ${ }^{10}$.

Will is often used to describe any procedure, process, sequence of actions in the present tense. It can be illustrated by the following striking example in Ukrainian:

Понесенні збитки ще більше погіршують фінансову ситуацію та економічний розвиток.

In Ukrainian and English legal documents, may and might express uncertainty, possibility, and they are characteristic of impersonal sentences (it might be possible, it might be useful, it might be instructive). For example:

Such an agreement might be one of a series of agreements entered into in the course of proceedings of the suit.

In practice, it might be possible to appoint one insolvency representative to administer multiple proceedings, or it might be necessary to appoint the same insolvency representative to each of the proceedings to be coordinated, depending upon procedural requirements.

Приділяйте особливу увагу суперечкам або ситуаиіям, які можуть ставити під загрозу підтримку міжнародного миру та безпеки.

${ }^{10}$ Berezhan L. V. (1997) Katehoriia sponukalnosti v suchasnii ukrainskii movi [The category of inducement in modern Ukrainian]. Extended abstract of PhD Thesis. Ivano-Frankivsk: Carpathian V. Stefanyk State University. 
The verbs may / might / could + Perfect Infinitive are widely employed to express hypothetical past situations.

The judge stated that the defendant might have been provoked by the victim.

Хоча ряду країн, можливо, вдалося залучити певні відчутні обсяги інвестииій в обробних секторах, особливо в текстильній промисловості, вони не вийшли на рівень конкурентоспроможності, необхідній для того, щэоб залишатися впливовими учасниками в иүій галузі.

A large number of special terms, clichés, fixed phrases, words with modal meanings of desire, need, prohibition, resolution, inadmissibility are used to express urgency in English and Ukrainian legal texts.There is also the use of lexemes with a marked expressiveness that create a special tone of a particular type of legal text.

The following language means are the most frequent in Ukrainian and English legal documents:

1. Imperative words, equivalents of modals, modal verbs expressing necessity (should, ought to), requirement (shall not, must not) obligation (must, need), recommendation (should, ought to), criticism of an action (shouldn't, oughtn't to). As an illustration, there are some examples.

All headings are for the reference purposes only and must not affect the interpretation of this Agreement. The Parties shall not be responsible for failure to fulfill their contractual obligations (other than payment obligations) in whole or in part if such failure is the result of ForceMajeure circumstances.

Потрібен негайний законодавчий акт, щэо дозволяє негайно направити гроші на соиіальні потреби.

Ми не можемо очікувати активної підтримки держави.

2. Conditional and subordinate clauses of time; they are introduced by the conjunctions as follows: if, as soon, when, provided, unless, etc ${ }^{11}$.

Examples of a modern plain English style contract:

If John Smith does not pay an instalment within one week from the day it is due a penalty will be incurred. The penalty is incurred every week an individual instalment remains unpaid.

If Mary Jones does not complete the house within one week from June 22019 a penalty will be incurred. The penalty is incurred every week the house is not completed.

11 Palashevskaya I. V. (2010) Yuridicheskiye imperativy [Legal imperatives]. Uchenyye zapiski Zabaykal'skogo gos. gumanitarno-ped. un-ta im. N. G. Chernyshevskogo. Ser. «Filologiya, istoriya, vostokovedeniye», no. 3 (32). Pp. 99-104. 
3. Rhetorical questions (types of that are incorporated into rhetorical questions). For example:

Would not that be a good solution to leave them?

Чому б нам самим не взятися за благоустрій наших домів та скверів?

4. Evaluative phrases that state desirability / unwillingness or the possibility / impossibility of any action indirectly (implicitly). For example:

The answer is to opt for arbitration.

There is no question that the police still needs reform...

Alternative dispute resolutions can be very helpful to both parties in electronic transactions, especially in cross-border complaints.

Зараз відкрилася унікальна можливість збудувати нову вертикаль влади.

5. The imperative and subjunctive moods, exclamatory sentences. Here is a Ukrainian example of an exclamatory sentence.

Давайте усвідомимо ие - та почнемо жити з надією!

Ellipses, reiterations, conditionals, emotional and expressive phrases, which include interrogative, imperative and declarative sentences, were the most frequent syntactic means of conveying the modal meanings of the functional and semantic field of volition.

As a rule, several language functions are realized in a legal text, while one or two operate as a functional dominant, that is, a text function that the author selects as a priority. The function of command (appellate) traditionally dominates in legal texts. The purpose of this function is to motivate or force the recipient to perform certain actions. In legal documents, two functions (denotative, command) are often simultaneously realized. The denotative function of the document is realized in the form of passing factual information, and the command function sets an imperative tone to the message.

In view of the foregoing, the following preparatory conditions for the success of legal imperatives can be distinguished: 1) the addressee has the ability and legal possibility to perform the action that is required of him; 2) by means of carrying out the required action there is a proper legal order in social reality; 3) the claim is legitimate and therefore indefeasible, enforceable.

In formulating legal imperatives in modern texts of legislative acts, preference is given to flexible regulatory structures, in which imperative statements are often presented as generalized statements. 
Thus, in the structure of legal imperatives, the speaker's attitude to the possible reaction of the addressee is already underlain. The imperative nature of legal discourse is gradual; it can be more or less imperative. The illocutionary power of the imperative is determined by the regulatory context and is related to the social significance of the requirement expressed by it. Thus, the most significant legal imperatives expressing the key value meanings of culture are concluded, first of all, in constitutional norms, endued with the highest legal force and, accordingly, with the highest degree of urgency. Consequently, the legal force of the imperative, concluded in the rule of law, is directly related to its illocutionary force. The illocutionary goal of legal imperatives is to bring what is due to the level of reality and at the same time to make reality due. In itself, a requirement does not make sense in legal discourse if it is not mediated by the instruction to follow it, resulting from the regulatory context.

\section{CONCLUSIONS}

Thus, the study of the imperative category in modern English and Ukrainian languages, as well as a thorough analysis of the language means of expressing the imperative nature of the legal document gives grounds to affirm that the language of the official style is abundant in stylistically marked linguistic means of influencing the addressee, in order to incite the commission both linguistic and post-communicative action.

An imperative is a linguistic category, realized in language and speech and represented by a set of features of a language unit, as well as the whole text, by which the author expresses a subjective attitude to the content or the addressee of the speech. An imperative is created by the mechanism of the will of the addressee through the category of modality, whose central importance is the order, as the main form of administrative activity of the communicant. An imperative category is the phenomenon of the presence of categorical orders: prohibitions and affirmative obligations underlying principles and rules that establish legal obligations and enshrine fundamental legal rights, as a result of the influence of the imperative method of legal regulation on public relations through the establishment of legal restrictions.

One of the most important stylistic features of a legal document is the imperative manifested both lexically and grammatically. While researching the language features of legal documents, we have noticed that a typical feature of Ukrainian and English legal documents is the use 
of a special, an official, and a bookish vocabulary. Legal texts in Ukrainian and English are also rich in cliches and fixed phrases. It is characteristic of using modal verbs of the imperative mood, infinitive sentences, repetitions, ellipses, forms of the indicative mood, language patterns of various syntactic structures and communicative approach (conditionals, interrogatives, narratives) with the verb in the indicative mood, exclamatives, passive constructions, etc.) to express the modal meanings of the functional and semantic field of volition and to convey the imperative nature of a legal document in the Ukrainian and English languages, too.

\section{SUMMARY}

The article deals with the analysis of the imperative category, which is the basis of modern legal discourse, embodied in different linguistic forms, and has various and split-level means of expression. The terms "document", "legal document" are defined; their characteristics are characterized. The semantic variety of meanings of imperative forms, which are implemented differently in legal texts, is described. The concept of volition, encompassing the meanings, desirability, and motivation is analyzed. The imperative and categories of the speech act theory, introduced by J.L. Austin, were thoroughly investigated. The lexical means of expressing imperative nature were revealed, i.e., the use of modal words with the meanings of necessity, obligation, and prohibition; the prevalence of professional terms, speech stereotyped patterns, standards, particles, interjections, conjunctions to convey particular meanings of a modality of . The use of various language patterns of different communicative approach and syntactic structure for expressing the imperative nature of a legal document is analyzed.

\section{REFERENCES}

1. Novoye $\mathrm{v}$ zarubezhnoy lingvistike [New in foreign linguistics] (1996). Moscow: Progress. (in Russian)

2. Biryulin L. A., Khrakovskiy V. S. (1992) Povelitel'noye predlozheniye. Tipologiya imperativnykh konstruktsiy [An imperative sentence. Typology of imperative constructions]. Moscow: Nauka. (in Russian)

3.Vezhbitskaya A. (1985) Rechevyye akty. Novoye v zarubezhnoy lingvistike [Speech acts]. Moscow: Progress. (in Russian) 
4. Sergiyevskaya L. A. (1995) Slozhnoye predlozheniye s imperativnoy semantikoy $\mathrm{v}$ sovremennom russkom yazyke [A complex sentence with imperative semantics in modern Russian] (Doctorate thesis), Moscow: Moscow Pedagogical University.

5. Rohozha V. H. (2005) Zasoby vyrazhennia volovoi modalnosti $\mathrm{v}$ tekstakh kodeksiv Ukrainy [Means of expression of volitional modality in the texts of the codes of Ukraine]. Extended abstract of PhD Thesis. Kyiv: NAS of Ukraine, Institute of Ukrainian Language.

6. Hyliaka O. (2014) Yurydychnyi dokument: osoblyvosti ta zakonodavche vykonannia [Legal document: specifics and legislative implementation]. Visnyk Natsionalnoi akademii pravovykh nauk Ukrainy, Pp. 165-171.

7. Duskayeva L. R., Protopopova O. V. (2011) Stilistika ofitsial'nodelovoy rechi [Stylistics of official speech] ]. Moscow: Akademiya. (in Russian)

8. Rybin P. V. (ed.) (2018). Uridicheskiy perevod [Legal translation]. Moscow: Prospekt. (in Russian)

9. Belyayeva E. I. (1992) Grammatika i pragmatika pobuzhdeniya: angliyskiy yazyk [Grammar and pragmatics of : English]. Voronezh: IVGU. (in Russian)

10. Berezhan L. V. (1997) Katehoriia sponukalnosti v suchasnii ukrainskii movi [The category of in modern Ukrainian]. Extended abstract of PhD Thesis. Ivano-Frankivsk: Carpathian V. Stefanyk State University.

11. Palashevskaya I. V. (2010) Yuridicheskiye imperativy [Legal imperatives]. Uchenyye zapiski Zabaykal'skogo gos. gumanitarno-ped. un-ta im. N. G. Chernyshevskogo. Ser. «Filologiya, istoriya, vostokovedeniye», no. 3 (32). pp. 99-104

\section{Information about the author:} Savchuk H. V.,

$\mathrm{PhD}$ in Philology, Associate Professor, Associate Professor at the department of Translation and Linguistics, International Humanitarian University, 33, Fontanska doroha str., Odesa, Ukraine, 65000 ORCID ID: orcid.org/0000-0003-4872-8722 